\title{
Draft dynamic student learning in design and manufacturing of complex shape parts
}

\author{
Ivana Kleinedlerová; Peter Kleinedler \\ STU MTF in Trnava \\ Detached workplace STU MTF Dubnica n/V \\ Dubnica nad Váhom, Slovakia
}

\author{
Alexander Janáč; Ivan Buranský \\ Slovak University of Technology in Bratislava \\ Faculty of Materials Science and Technology in Trnava \\ Trnava, Slovakia
}

\begin{abstract}
The contribution deals with the dynamic teaching of students through blended learning and teaching online distance teaching which can be considered nowadays to be a very effective and dynamic education of students. Content of the article is focused on the sphere of programming with $\mathrm{CNC}$ machines and use Cax systems for the production of a particular shape complex part - shearing knife. The article presented also proposed effective teaching resources. The motivation for solution of this project is that dynamic education leads students to gaining experience and skills, individual identification of the issue, creativity, suggestion of problem solving variations. The achieved way of education and its confirmed and verified positive results can be applied for various target groups of students and their fields of study.
\end{abstract}

Keywords-dynamic education blended learning; e-learning; CA systems.

\section{INTRODUCTION}

Latterly, is recorded growth of the use of information technologies that can be considered as tools for improving the efficiency of teaching students. In this regard, the most suitable technology of education through e-learning, e.i. electronic education can be considered appropriate [1]. The multi-medial learning in the form of electronic teaching materials being available on the Internet has been concerned. One of the advantages of the e-learning way is a possibility of students to communicate with a teacher or other workers in a distance way what results in efficiency and speed of the education independently of the place of school [2]. Current trend in education has also been the so called blended learning - combined education which represents the conventional teaching students by a teacher in a classroom and the elearning education [3].

The aim of this contribution is to present a proposal on-line dynamic teaching students of department Computer-aided manufacturing technologies for the production of a particular shape complex part - shearing knife, which is part of the rolling forming tool for the production of extrusion. Students propose a design and documentation process for the production by blended learning through classroom teaching and the realization of the knife follow the classroom through online distance teaching. In practical terms, it means to prepare for students e-learning instructional materials in the manufacturing of forming tools and work in specific CAD and CAM systems. Then use throughout the realization of shearing knife CAD and CAM systems - that automate the design and technological work and production, and ultimately use blended learning and on-line distance learning, in which students are able to follow the entire process of production shearing knife. The aim of teaching students is also achieved, to design a suitable method of making from the perspective of rationalization - that is, to design production of knife in achieving the in minimum time, in the required accuracy of product and minimize consumption of materials. In the dynamic e-learning and teaching is an advantage for students to have the opportunity to justify the steps taken with the possibility of asking questions of the real-time production knife.

The project is carried out at field offices of STU MTF Dubnica nad Váhom, that does not have a machine park. Students thus solving technical proposal knife through CAD and CAM systems and production of knifes follow classroom using web camera in the workplace STU Trnava. On the present belongs to the advanced manufacturing technology 5axis machining. The 5-axis machining belongs at present to the most frequent used production methods for a single-part production as well as for a small-butch production. This is a progressive method which markedly reduces the production time and thereby the factory price. The 5-axis machining production requires qualified manpower from the point of the workshop programming as well as the CAM system programming. Therefore, the shearing knife production will also take place through the progressive machining methods.

\section{TOOLS OF DYNAMIC EDUCATION FOR STUDENTS AND BASIS FOR ITS IMPLEMENTATION}

Practical experiences confirm, that any information from internal and external school environment is necessary to consider, generalize, sort and analyze in the fastest possible way. Therefore the ground of dynamic education is to motivate students to adopt techniques of active work with informations, ergo searching process, relevant information sorting and combining of knowledge, which leads to creation and vindication of own opinion. The main difference between traditional educational approach, based on passive acceptance of knowledge and active dynamic education is, that the traditional education in form of lectures and seminars gives students „ready-made " theoretical studying materials, while practical-dynamical exercises gives space for gaining skills, acknowledging principles of team work, resp. Solving of individually given tasks, when is necessary systematically search for and to gather the newest information about given 
subject. Combination of this two educational approaches is preferred to gain effective dynamic education model. Techniques of effective dynamic education leads students to individual identification of the issue, creativity, experiments, suggestion of problem solving variations, reevaluation of solutions, visualization, outcome testing and feedback. It's implementation into educational process leads to transformation of student position from receivers of theoretical information to the problem solvers. Active action of students in education rise their motivation for gaining new knowledge and skills and experience and enable straight theory application on real conditions simulated in multimedia class [4].

Currently accepted and worldwide implemented basic trends of applied designed dynamic education for students were also reflected in our project and can be summarized in the following aspects [4]:

- Allover system of education and practical education of students for all parts of component production implementation.

- Education and practical education continuity throughout all the study on university.

- Combining of education and practical education from engineering companies point of view (classes realized by companies, specialized practice for students offers and so on) with self-education of students.

- "Learning" become a part of given tasks and projects solving for students and is adequately appreciated, what is for them important motivation factor.

- Application of modern educational and training methods (like e-learning, learning-by-doing, visual learning etc.) through multimedia and internet technologies.

Dynamic methods of education in general is possible to divide in three groups [4]:

1) Informational methods: Contains mainly lectures, seminars, conference, video projection, systematical observation, and instruction with computer assistance, creativity exercise.

2) Simulation methods: Contains examples, program group exercises.

3) Practical education: Involves practical education of students while real problem solving, e.g. Production proposition.

According to the authors, who conducted projects of dynamic teaching students, they considered as her effective and most used resources [4]:

1) Multimedia e-learning: Concept multimedia in this case express connection of image, text or visual informationeducational texts. Virtual education offers in electronic way many studying materials and information and by this form of education is maximally used IT and internet.

2) Visualized education as part of e-learning : Visualized education might be defined as giving information via illustrations, photographs, graphs, symbols, pictures or other visual models. Goal and assignment of visualized education is to simplify and shorten the process of introduction of complex information, in other words, enable to understand the thought on first sight. Higher level of visualized education presents the presentation of dynamic visual information, for example instruction video, video-clips and animations, instead of static only visualization, as is defined above.

3) „, On the job training “ - OJT : Currently educationally promising developing area of teaching, is the use of on-line camera with high picture quality in solving of specific given tasks (projects), and troubleshooting. This is the solution of practical examples of manufacturing components in the presence of the teacher, providing advices to solve of given project, practical skills training, using the same techniques as in engineering practice, analysis of failure technique and the like. An on-line conference led by a teacher, team members communicate each other and suggest possible solutions to production of parts. These were used in our dynamic education for students of PPT proposition, and within were proposed and presented effective ways of education for reaching desired target - effective dynamic education for students of PPT (Fig. $1)$.



Fig.1. Illustration of Videoconferencing [4]

\section{The State Education DePartment OF COMPUTER AIDED MANUfACTURING TECHNOLOGIES FOR FIELD OFFICES DUBNICA}

On the present our Detached workplace (hereinafter DP) does not possess any machineries which could be used for practical teaching of the mentioned section students.

Most of such activity is substituted by a videodemonstration of production of selected components or visiting engineering factories. Students thus miss the integrated viewpoint and practical skill with the design and production of e.g. a specific component where they could have a possibility of the self-realization, verifying their knowledge acquired at the practical example as well as the possibility to suggest the more potential effective production. Teaching the subject: Computer support of production technologies has been a key subject of the section named Computer support of production technologies which is offered by Slovak University of Technologies, Faculty of Material Science and Technologies (hereinafter STU MTF). Therefore, is this problem solved by the creation of on-line learning taking place 
in the online classroom, which is interconnected in collaboration with the Center of Excellence for the MTF STU Trnava. It is a workplace that has a modern machine park.

\section{Creating Training Materials For CAD Modeling AND CAM PROGRAMMING}

Given the interest of teachers to provide students with high quality and up to date training materials for the teaching of the subject, the educational system has been oversaturated with technological (computer) information in the form of multimedial education texts trying to give students quality information and the latest knowledge for the concrete educational subject in the time as quickly as possible [5]. The offered educational materials in the framework of the subject: Computer support of production technologies alternate from each other depending upon their author, required tasks being solved, practical contribution, etc. That is why in the framework of soluting this project, the educational materials have been modified and reduced in such a way so that students can study the necessary problem of the 5-axis machining, modeling and programming in the relevant CA system and based on the obtained knowledge they are able to solve also given tasks within the framework of their self-study. Educational texts were necessary to create in regard to knowledge level of students and regarding their previous secondary school study or practical skills from the sphere of engineering production of components.

The educational materials for students were created:

1) Electronic textbooks : from time to time are actualized, which contains simulations, animations and presentations. These are presented to students on the official page of faculty, where students can download it anytime or they have been send to academic information system in section ,documents", where they can always check actualized materials and download it. Electronic textbooks are published mainly in hypertext form , and are appropriately elaborated even for self education of subject without a teacher. E- learning textbooks uses animations, voice guide, dictionary, text finder, cross reference related to the electronic publication theme on the internet.

2) In the PowerPoint program: in the form of slides which included basic information from the sphere production components, design and manufacture of forming tools, modelling and by means of CA system programming whereby the most important information was highlighted with bold letters (Fig. 2). The information was contentually balanced for the needs of soluting the given task. Materials are available to students on-line at a distance without physical contact and attendance at local schools, too.



Fig.2. The slide created in MS PowerPoint

3) In program "Notepad": was created the final test (Fig.3) in each teaching area to verify their own knowledge gaps and students. Its advantage is that it allows students to get immediate feedback on the ability to obtain new knowledge [6]. Test was created to positively motivate students to engage in self-study and the ability to understand the basic things that are expected of this test. That notepad is located on a server MTF - KAIA, and is available to students at any time and from anywhere (with Internet access), and outside the classroom, too. Testing of students in the program "Notepad Notepad" took place at the beginning of each lesson to verify their knowledge acquired in previous hours of teaching [7]. Also the test was used in the final evaluation of the student.



Fig.3. Test created using "Notepad" [11]

4) In programs MS OFFICE: were developed textpictorial procedures for modeling (Fig. 4) and programming of the knife in the relevant CA system. These were created for all areas of modeling and programming steps of knife. Materials are available to students on-line at a distance without physical contact and attendance at local schools. 




Fig.4. Text-pictorial procedures for modelling of knife

5) The video instructions: to create a text-pictorial procedures were created the video instructions (Fig. 5). As the component can be modeled several techniques - methods of modeling and programminng, were presented in video-all manual modeling techniques that offer a specific program design, in which the students drew. To enable students to understand the various techniques of painting. User-created video is also available to students on-line at a distance without physical contact and attendance at local schools.



Fig.5. . Video-manual for programming

6) Supplemental materials: since not all students solving the project had experiences with an engineering component manufacturing, it was necessary for them to create even more extensive teaching background. These have been addressed in the form of presentation materials in PowerPoint that contain text with Internet connections for graphics and video-examples of text from a given field of design shaping tools, design and manufacture of engineering components using the CA system and 5-axis machining. Materials are also available to students on-line.

\section{Programming Production of KNIFE USing CAM SYSTEM}

When creating a program in NC machining module used CAD / CAM system based on the model drawing knife. The first step for the realization of the production was the creation of the technological process. After finishing programming, were all programs sent like as CL data using a post processor Tebis been sent to the server, where the staff at MTF Trnava searched, downloaded to a CNC machine and used for machining. From an economic perspective and the time it starts out where the use of CAM system very convenient. Most major CAD / CAM systems can cover almost the entire production cycle from idea creation, through engineering design, creating NC programs and technological processes [8].

Using such a system, in our case, reduce the cost and time required, especially in the creation of $\mathrm{NC}$ programs on the grounds that, given the complexity of the shape produced a knife manual programming would be very difficult to impossible. Teaching students by PPT is realized in the socalled. multimedia classroom and focuses on teaching their own teaching methods for practical training in the field of engineering practice called. method OJT - on the job training.

This is the adaptation and development program for students who are preparing for target of specific job position or area of expertise in the field of drawing machine parts using CAD systems, programming and simulation of manufacturing parts using CAM system for the production and implementation of manufacturing machines using remote transmission via webcam from Centre of excellence of 5-axis machining in Trnava. Within the frame of the e-learning education, students were enabled to program the production of the knife on your personal computer in the classroom, in the presence of a teacher. There were two monitors in front of the students for better understanding of the programming procedures. The students could watch the teacher's work and his/her visual demonstrations of the programming procedure on one monitor. On the other monitor, the students saw their own work and programming. The students thus could simultaneously understand the principle of the component programming by the teacher with their own activity whereby they could ask questions immediately and understand the principle of programming.

This way of learning has approved to be a very effective method for understanding the given problem.

After entering all necessary operations are generated graphical representation of machined with semi-attachment representation - simulation (Fig. 6). 




Fig.6. Graphic display during production knife - a simulation

\section{IMPLEMENTATION OF BLADE PRODUCTION AND ITS EVALUATION}

\section{1) Production of knife 3-axis and 5-axis machining}

Production of knife had to be carried out either directly on the machine tool. Since students have the opportunity to be directly in contact with the machine tools and directly see its production, this possibility was provided by them so. on-line learning in real time. On-line teaching students with software and hardware support to allow students to acquire required knowledge and skills at a distance without physical contact and attendance at local schools MTF in Trnava. Therefore, it can be seen in our case, a very effective and alternative way of teaching. Within this dynamic learning, students were provided a computer program Team Viewer (Fig.7).

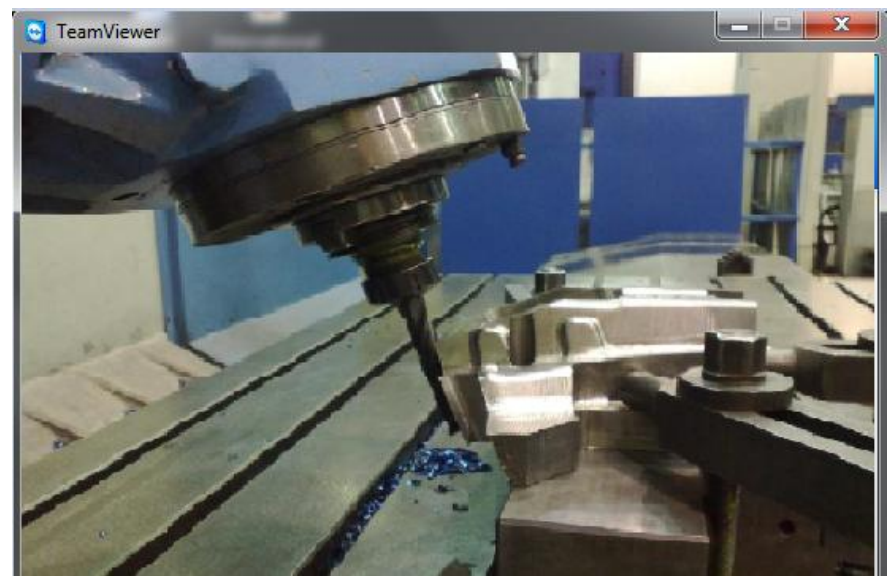

Fig.7. On-line monitoring of production of knife on the computer

When it is activated on a computer student and computer teacher, to ensure video and audio data transmission over the Internet, in which students had the opportunity to see and hear

the teacher's instructions and work on their monitors. Since it was on track to manufacture blade machine tool, teachers connect to your computer web camera and directed it to the machine tool for students to see the whole process of programming and production knives. Teachers had the opportunity to explain to students adjust production machinery for manufacturing, and students could ask him any questions in real time. As part of the transfer was also simulated production knife with $\mathrm{CNC}$ and students to submit proposals to upgrade for innovation the programmed production. The aim of teaching students was the rationalization of work in the production of knife.

Therefore, the way the strategy of design documentation and production tool has been chosen so as to ensure a minimum of preparation and production times, subject to compliance with the required quality [9]. However, the acquisition of programming skills and a better understanding of production Engineering components were intentionally selected component complex shapes that can be produced 3-axis continuous cultivation methods (milling, drilling) and 5 -axis cultivation methods. This work was completed on the shearing knife, which its production shifted to the heat treatment hardening shops. Since no work in Trnava lacks such technology, the students were introduced to the heat also working with video and on-line teaching of business component that worked. Students have a unique opportunity to monitor the progress of hardening the knife and practically familiar with this technology.

\section{2) Manual machining and assembly tool in unveiling}

After burring the piece should be ready for further manual processing (Fig. 8), which were also able to see the students using the on-line transmission and learning. The first act was carried burring sites, whereas the complexity of the blade shape and the lack of non-conforming areas, it was not possible to choose the option clamping in a vice or with magnetic clamping the machine working.

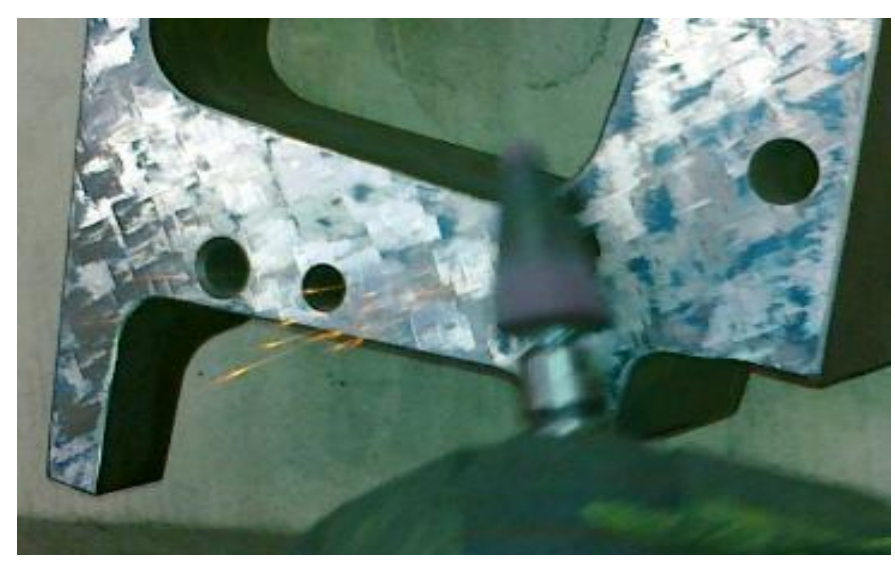

Fig.8. Removal base area - the burring

After burring was necessary to achieve a flatness of at least $90 \%$ of the area because poignancy perfect tool for folding and compacting reduction.

Placing a tool in the kit has been carried out by qualified personnel, who have long experience in this field; after subsequent machining of the mold tool, further by incorporation of different grain grinding stones. After incorporation of the upper OT and lower UT part, molds were taken to the press, where it was being worked on. For this 
work to eliminate the remaining allowance $0.05 \mathrm{~mm}$ on both parts by qualified professionals, which it used in abrasive bodies clamped straight grinder. This operation was the most important to get right and precision moldings produced by crimping tool. The result was a production made knife that meets all the required parameters (Fig. 9). We can state that the selected way of machining the component has met the required aims. Based on the performed strategy of the production and character of the selected component, the students could understand the strategies of the programming procedure 3-axis and 5-axis machining. They could think forwards with reference to minimization of the production costs and working time.



Fig.9. The final shape of manufactured knife

\section{CONCLUSION}

Conventional methods of education currently adequately reflect the requirements of the labor market and practical information to gain knowledge and skills in the field of engineering technology in their teaching [10]. Theoretical knowledge that students acquire in traditional education are not be able to apply in practice and at the same time, these data largely short-term in nature. Therefore, it is necessary to apply innovative forms of education in this area. The contribution of the article was to present a dynamic learning design in the design and manufacture of complex shape parts, which in our view has brought efficiency in the acquisition of practical skills and the acquisition of new knowledge for students. The presented method of teaching has proved to be very beneficial in teaching effectiveness and meet our desired goals. Students expressed in solved project ambit rising interest in study. In comparison with classical way of education students showed their independence and creativity within production design of the component.
They've gained practical experience, which they've wouldn't achieve with classical type of education. Through visual learning they can better connect informations and understand relations between them. By that they can better understand to the new concepts, confidently link to previously achieved knowledge and in other similar projects solving, they didn't have problem to solve individual tasks. We are convinced that given dynamic way of education is great motivation for students and good base for their adaptation in engineering practice.

This contribution is worked out in the frame of the KEGA

047STU-4/2012 project - Realisation of On-line classroom for dynamic education of secondary technical schol and university students focused on design and manufacturing of freeform surfaces.

\section{REFERENCES}

[1] Š. Svetský, I. Kleinedlerová and P. Kleinedler "Počitačová podpora výučby technológií - galvanotechnika a obrábanie." Zborník prednášok. 53. Medzinárodná galvanická konferencia. Kočovce, 2011, pp. 47-53.

[2] B. Divjak, N. Begičević "Imaginave acquisition of knowledge - strategic planning of E-learning". Cavtat, ITI 2006, 2006, pp. 36-43.

[3] N. Begičević, B. Divjak and T. Hunjak "Development of AHP Based model for decision making on E-learning implementation". Journal of information and organizational sciences, Vol. 31, 2007, pp. 13-24.

[4] I. Kleinedlerová, A. Janáč, P. Kleinedler, I. Buranský "Dynamic Educational Process Efficiency Improvement for Students of Computer Production Technologies Support Subject". IJECCE, Vol. 4, 2013, pp. 446-450.

[5] O. Moravčík, Š. Svetský, F. Hornák, D. R. D. Sobrino and J. Štefánková "Experiences with the Personalised Technology Support for Engineering Education". 21st Annual Conference of the Australasian Association for Engineering Education. Sydney, 2010, pp. 532-538.

[6] Ch. Adiele, E. D. Nwanze "The Dynamics of Interactivity Modeling for e-learning". Knowledge management and e-learning, Vol. 2, 2010, pp. 370-382.

[7] B. H. Khan "A Framework for E-learning". 2001. URL: http://bookstoread.com/framework. ( 18.12.2012).

[8] N. Buzađija „Istrazivanje efikasnosti primjene Blended Learning sustava u nastavi inforrmatike u srednjem obrazovanju ". Život i škola, Vol. LV, No. 22. Studeni: 2009, pp. 50-61.

[9] P. Kǒš "Implementation of e-learning Technologies in the workplace". Kvalita inovácií a prosperita, Vol. 10, 2006, pp. 7-15.

[10] Š. Svetský, I. Kleinedlerová, P. Kleinedler “ Počitačová podpora výučby technológii - galvanotechnika a obrábanie”. 53. medzinárodná galvanická konferencia. Kočovce, 2011, pp. 47-53.

[11] A. Reháková, D. Rusková, Š. Svetský “Modeling multilingual support systems for trainee teachers of technical branches via the use of ICT". Problemy doksztalcania i doskonalenia zawodowego nauczycieli.om, 2009, pp. 219-223. 